\title{
GUCY2C Antibody
}

National Cancer Institute

\section{Source}

National Cancer Institute. GUCY2C Antibody. NCI Thesaurus. Code C123806.

Any immunog lobulin that recognizes heat-stable enterotoxin receptor. 